\title{
Effect of iron oxide on nitrification in two agricultural soils with different $\mathbf{p H}$
}

\author{
Xueru Huang ${ }^{1}$, Xia Zhu-Barker ${ }^{2}$, William R. Horwath ${ }^{2}$, Sarwee J. Faeflen ${ }^{1}$, Hongyan Luo ${ }^{1}$, Xiaoping Xin ${ }^{1}$, and \\ Xianjun Jiang ${ }^{1}$ \\ ${ }^{1}$ College of Resources and Environment, Southwest University, 2 Tiansheng Road, Beibei, 400715 Chongqing, China \\ ${ }^{2}$ Biogeochemistry and Nutrient Cycling Laboratory, Department of Land, Air and Water Resources, \\ University of California Davis, CA 95616, USA
}

Correspondence to: Xianjun Jiang (jiangxj@ swu.edu.cn)

Received: 30 April 2016 - Published in Biogeosciences Discuss.: 17 June 2016

Revised: 7 September 2016 - Accepted: 20 September 2016 - Published: 7 October 2016

\begin{abstract}
Iron $(\mathrm{Fe})$ affects soil nitrogen $(\mathrm{N})$ cycling processes both in anoxic and oxic environments. The role of $\mathrm{Fe}$ in soil $\mathrm{N}$ transformations including nitrification, mineralization, and immobilization, is influenced by redox activity, which is regulated by soil $\mathrm{pH}$. The effect of Fe minerals, particularly oxides, on soil $\mathrm{N}$ transformation processes depends on soil $\mathrm{pH}$, with $\mathrm{Fe}$ oxide often stimulating nitrification activity in the soil with low $\mathrm{pH}$. We conducted lab incubations to investigate the effect of $\mathrm{Fe}$ oxide on $\mathrm{N}$ transformation rates in two subtropical agricultural soils with low $\mathrm{pH}$ (pH 5.1) and high $\mathrm{pH}(\mathrm{pH} 7.8) .{ }^{15} \mathrm{~N}$-labeled ammonium and nitrate were used separately to determine $\mathrm{N}$ transformation rates combined with $\mathrm{Fe}$ oxide (ferrihydrite) addition. Iron oxide stimulated net nitrification in low-pH soil ( $\mathrm{pH} 5.1)$, while the opposite occurred in high-pH soil ( $\mathrm{pH}$ 7.8). Compared to the control, Fe oxide decreased microbial immobilization of inorganic $\mathrm{N}$ by $50 \%$ in low-pH soil but increased it by $45 \%$ in high-pH soil. A likely explanation for the effects at low $\mathrm{pH}$ is that Fe oxide increased $\mathrm{NH}_{3}-\mathrm{N}$ availability by stimulating $\mathrm{N}$ mineralization and inhibiting $\mathrm{N}$ immobilization. These results indicate that $\mathrm{Fe}$ oxide plays an important role in soil $\mathrm{N}$ transformation processes and the magnitude of the effect of $\mathrm{Fe}$ oxide is dependent significantly on soil $\mathrm{pH}$.
\end{abstract}

\section{Introduction}

The effect of soil $\mathrm{pH}$ on redox sensitivity of soil $\mathrm{N}$ transformations, especially nitrification, is receiving increasing attention. Nitrification is a biological process that spans the full range of oxidation states of nitrogen $(\mathrm{N})$ from $-3(\mathrm{am}-$ monium: $\mathrm{NH}_{4}^{+}$) to +5 (nitrate: $\mathrm{NO}_{3}^{-}$), including compounds with intermediary oxidation states such as hydroxylamine $\left(\mathrm{NH}_{2} \mathrm{OH}\right)$ and nitrite $\left(\mathrm{NO}_{2}^{-}\right)$, which are formed to various degrees during nitrification. This process can also produce reactive intermediates such as nitrogen oxides $\left(\mathrm{NO}_{x}\right)$ and nitrous oxide $\left(\mathrm{N}_{2} \mathrm{O}\right)$ affecting air quality and global climate. The role of iron $(\mathrm{Fe})$ oxides in the soil nitrification process both in anoxic (Clément et al., 2005; Yang et al., 2012; Ding et al., 2014) and oxic environments (Jiang et al., 2015a) is recognized, yet is rarely identified in biogeochemical models that predict global $\mathrm{N}$ cycle processes. Iron and its oxides are found in abundance in many soils, with large amounts of $\mathrm{Fe}$ oxides being typically found in subtropical and tropical soils. Thus, knowing the relationship between Fe oxides and the soil nitrification process is especially important for understanding its influence on $\mathrm{N}$ cycling processes.

The direct participation of $\mathrm{Fe}$ in nitrification was first proposed as the Feammox reaction ( $\mathrm{Li}$ et al., 1988; Sawayama, 2006), referred to as anaerobic $\mathrm{NH}_{4}^{+}$oxidation coupled to $\mathrm{Fe}(\mathrm{III})$ reduction. Nitrate and dinitrogen $\left(\mathrm{N}_{2}\right)$ are produced during this process (Luther et al., 1997; Clément et al., 2005; Sawayama, 2006; Shrestha et al., 2009; Yang et al., 2012). Feammox usually occurs in anoxic conditions of saturated soils such as wetland (Clément et al., 2005; Shrestha et al., 2009), suggesting that $\mathrm{Fe}$ oxides can act as an electron acceptor and play a critical role influencing $\mathrm{N}$ reactions in the $\mathrm{ab}$ sence of oxygen $\left(\mathrm{O}_{2}\right)$ (Schuur and Matson, 2001; Wang and Newman, 2008; Liptzin and Silver, 2009; Park et al., 2009; Ding et al., 2014). 
Iron can also participate in other soil $\mathrm{N}$ transformations (e.g. $\mathrm{N}$ mineralization, heterotrophic denitrification, and chemodenitrification) via the Fe reduction-oxidation (redox) cycle, both biotically and abiotically (Li et al., 2012; ZhuBarker et al., 2015). In 10 agricultural soils, Zhu et al. (2013) found that Fe ranked higher than any other intrinsic soil property in affecting nitrous oxide $\left(\mathrm{N}_{2} \mathrm{O}\right)$ production and emission. In wetland soils, sediments, or anoxic microsites, oxidation of $\mathrm{Fe}$ (II) coupled to $\mathrm{NO}_{3}^{-}$reduction proceeds simultaneously via biotic and abiotic pathways (Senn and Hemond, 2002; Davidson et al., 2003; Straub et al., 2004; Weber et al., 2006; Smolders et al., 2010). Under oxic or anoxic conditions, the interaction between biotic (e.g. Fe(III)-reducing microorganisms) and abiotic factors (e.g. $\mathrm{pH}$ ) mediates the redox cycle of $\mathrm{Fe}$, which can lead to organic-matter decomposition and thus $\mathrm{N}$ mineralization (Lovley and Phillips, 1986; Roden et al., 2004; Sahrawat, 2004; Weber et al., 2006; Bauer and Kappler, 2009; Hall and Silver, 2013). The oxidation of $\mathrm{Fe}(\mathrm{II})$ stimulates organic-matter decomposition and is assumed to occur via two mechanisms: (1) organic-matter oxidation (driven by reactive oxygen species) and acidification; (2) the release of dissolved organic carbon that can complex with $\mathrm{Fe}$. A study on diverse west African rice soils showed that $\mathrm{NH}_{4}^{+}$production in submerged soils was significantly correlated to reducible Fe(III). It suggests that Feorganic-matter complexes are important in influencing $\mathrm{NH}_{4}^{+}$ production in submerged soils (Sahrawat, 2004).

Iron oxides can affect microbial groups and their activities. Meiklejohn (1953) found that a small amount of $\mathrm{Fe}$ (0.1-6 mg L $\left.{ }^{-1}\right)$ stimulated the growth of nitrifying bacteria and increased the oxidation of $\mathrm{NH}_{3}$ to $\mathrm{NO}_{2}^{-}$, whereas high concentrations of $\mathrm{Fe}\left(>112 \mathrm{mg} \mathrm{L}^{-1}\right)$ were toxic to nitrifying bacteria. Studies on Fe requirements for ammonia-oxidizing bacteria (AOB) showed that when the Fe concentration in the medium of Nitrosomonas europaea increased from 0.2 to $10 \mu \mathrm{MFe}$, the activities of both ammonia monooxygenase and hydroxylamine oxidoreductase decreased (Wei et al., 2006). A recent study observed that the abundance of AOB and ammonia-oxidizing archaea (AOA) in an acidic forest soil decreased after the addition of hematite, a type of Fe oxide (Jiang et al., 2015a). Nevertheless, it is difficult to generalize the response of nitrification to $\mathrm{Fe}$ oxide addition under varying soil $\mathrm{pH}$. This is because AOA and AOB occupy different soil niches according to soil $\mathrm{pH}$, i.e., AOA dominates nitrification activity in acidic soils, while AOB dominates it in alkaline soils (Stopnišek et al., 2010; Gubry-Rangin et al., 2011; Isobe et al., 2012; Jiang et al., 2015b).

We hypothesized that the effect of Fe oxide on $\mathrm{N}$ transformations depends to a large extent on soil $\mathrm{pH}$. Two major questions are posed:

i. Does the presence of $\mathrm{Fe}$ oxide influence the rate and amount of nitrification, $\mathrm{N}$ mineralization, and $\mathrm{N}$ immobilization in soils with varying $\mathrm{pH}$ ? ii. What is the mechanism of Fe oxide that influenced $\mathrm{N}$ transformations under different soil $\mathrm{pH}$ ? To investigate $\mathrm{Fe}$ oxide affects on $\mathrm{N}$ dynamics in soils with different $\mathrm{pH}$, a stable isotope $\left({ }^{15} \mathrm{~N}\right)$ method was used to measure the gross rates of $\mathrm{N}$ transformations.

\section{Material and methods}

\subsection{Site description and soil sampling}

Field sites are located at Beibei, Chongqing, China, which has a mean annual temperature of $18.2^{\circ} \mathrm{C}$, annual rainfall of $116 \mathrm{~cm}$, and a frost-free period of 359 days per year. Soil samples were collected from agricultural land $\left(29.70^{\circ} \mathrm{N}, 106.38^{\circ} \mathrm{E}\right)$ with low-pH soil ( $\left.\mathrm{pH} 5.1\right)$ and a hill site $\left(29.75^{\circ} \mathrm{N}, 106.40^{\circ} \mathrm{E}\right)$ with high-pH soil $(\mathrm{pH} 7.8)$ in March, 2015. Both soils were developed from a Cenozoic Quaternary Holocene (Q4) alluvium and are classified as Fluvents, Udifluvents (USDA, soil taxonomy) (Soil Survey Staff, 2014). The low-pH soil was sampled from maize plots in a rotation system with sweet potato under conventional cultivation over 10 years. In the spring maize and autumn sweet potato growing seasons, $\mathrm{N}$ fertilizers were conventionally applied as urea at rates of 75 and $225 \mathrm{~kg} \mathrm{~N} \mathrm{ha}^{-1}$, respectively. The high-pH soil was sampled from a pear orchard, which was converted from cropland 3 years ago and has not been fertilized or tilled since the conversion.

Composite soil samples derived from five auger borings to $0-20 \mathrm{~cm}$ depth were brought immediately to the laboratory. Stones, dead plant material, roots, and visible soil fauna were removed. One portion of the soil was slightly air-dried to reach a gravimentric moisture content of about $15 \%$, sieved to $2 \mathrm{~mm}$, and stored at $4{ }^{\circ} \mathrm{C}$ prior to use (within 2 months). Another portion of the soil was air-dried, passed through a $1 \mathrm{~mm}$ sieve, and used for chemical analyses (Jiang et al., 2015a).

\subsection{Soil chemical analyses}

The results for the soil chemical properties are shown in Table 1. Soil $\mathrm{pH}$ was measured using a soil-to-water ratio of $1: 2.5(v / v)$ by a DMP-2 $\mathrm{mV} / \mathrm{pH}$ detector (Quark Ltd, Nanjing, China). Total N (TN) and soil organic-matter (SOM) contents were determined by a Macro Elemental Analyzer (Elementar Analysensysteme GmbH, Hanau, Germany). Total soil Fe was extracted with $\mathrm{HNO}_{3}-\mathrm{HF}-\mathrm{HClO}_{4}$ and measured using atomic absorption spectrophotometry with a graphite furnace (GFAAS, Z-8200, Hitachi, Tokyo, Japan). Available $\mathrm{Fe}$ was extracted with the diethylenetriamine penta-acetic acid (DTPA) method and analyzed by inductively coupled plasma optical emission spectrometry (ICP-OES; Thermo Element iCAP6000 (Radial), Cambridge, UK). 
Table 1. Chemical properties of the soils with low $\mathrm{pH}$ and high $\mathrm{pH}$. Different letters represent statistically significant differences between treatments at $P<0.05$.

\begin{tabular}{lccccccc}
\hline Soil type & $\mathrm{pH}$ & $\begin{array}{c}\text { Organic matter } \\
\mathrm{g} \mathrm{kg}^{-1}\end{array}$ & $\begin{array}{c}\text { Total } \mathrm{N} \\
\mathrm{g} \mathrm{kg}^{-1}\end{array}$ & $\begin{array}{c}\text { Total Fe } \\
\mathrm{g} \mathrm{kg}^{-1}\end{array}$ & $\begin{array}{c}\text { Available } \mathrm{Fe} \\
\mathrm{mg} \mathrm{kg}^{-1}\end{array}$ & $\begin{array}{c}\mathrm{NO}_{3}^{-} \mathrm{N} \\
\mathrm{mg} \mathrm{Nkg}^{-1}\end{array}$ & $\begin{array}{c}\mathrm{NH}_{4}^{+}-\mathrm{N} \\
\mathrm{mg} \mathrm{Nkg}^{-1}\end{array}$ \\
\hline $\begin{array}{l}\text { Fluvents } \\
\begin{array}{l}\text { Udifluvents } \\
\text { Fluvents }\end{array}\end{array}$ & 5.1 & $18.0 \pm 0.26 \mathrm{a}$ & $0.73 \pm 0.01 \mathrm{a}$ & $16.3 \pm 0.08 \mathrm{~b}$ & $132 \pm 4.04 \mathrm{a}$ & $10.3 \pm 0.85 \mathrm{a}$ & $1.54 \pm 0.19 \mathrm{~b}$ \\
$\begin{array}{l}\text { Udifluvents } \\
7.8\end{array}$ & $13.9 \pm 0.11 \mathrm{~b}$ & $0.68 \pm 0.03 \mathrm{a}$ & $27.5 \pm 0.04 \mathrm{a}$ & $5.64 \pm 0.49 \mathrm{~b}$ & $4.68 \pm 0.48 \mathrm{~b}$ & $2.44 \pm 0.16 \mathrm{a}$ \\
\hline
\end{tabular}

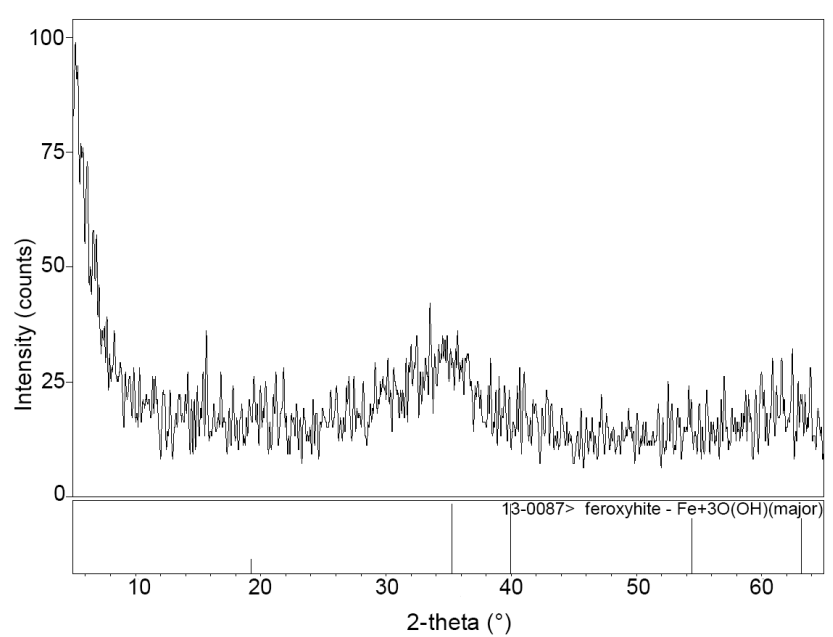

Figure 1. X-ray diffraction pattern of ferrihydrite.

\subsection{Preparation of Fe oxide treatments}

Ferrihydrite was used as a precursor to produce $\mathrm{Fe}$ oxide. The method for ferrihydrite preparation in this study was modified from the method described by Lovley and Phillips (1986). Briefly, Fe(III) sulfate hydrate $\left(\mathrm{Fe}_{2} \mathrm{~S}_{3} \mathrm{O}_{12} \cdot x \mathrm{H}_{2} \mathrm{O}\right)(40 \mathrm{~g})$ and ultrapure water $(500 \mathrm{~mL})$ were first mixed and stirred. Then, the $\mathrm{pH}$ of mixture was adjusted to 7-8 with $1 \mathrm{~mol} \mathrm{~L}^{-1} \mathrm{KOH}$ and left to settle until entirely precipitated. The precipitate was centrifuged $(2800 \mathrm{~g}, 5 \mathrm{~min})$ and washed with ultrapure water five times until the suspension had a conductivity of $<20 \mu \mathrm{S} \mathrm{cm}^{-1}$. The particle density and original $\mathrm{pH}$ of ferrihydrite in the final suspension were $87 \mathrm{~g} \mathrm{~L}^{-1}$ and 3.7, respectively. One portion of the suspension was freeze-dried and then analyzed for ferrihydrite using the X-ray diffractometer (XRD) (PANalytical B.V., Holland) (Fig. 1). The remaining ferrihydrite suspension was divided into two parts. The $\mathrm{pH}$ of these two parts were adjusted to either 5.1 or 7.8 , the same as the initial $\mathrm{pH}$ in low-pH or high-pH soils.

For each soil, two Fe oxide treatments were applied: non$\mathrm{Fe}$ (control) and $\mathrm{Fe}$ treated (the $\mathrm{pH}$ of ferrihydrite was adjusted to the same as soil $\mathrm{pH}$ ). Ferrihydrite was added at $3 \%$ $(w / w)$. The low-pH soil without or with Fe oxide amendment was designated as $\mathrm{pH} 5.1$ control or $\mathrm{pH} 5.1+\mathrm{Fe}$, while the high-pH soil without or with $\mathrm{Fe}$ oxide amendment was designated as $\mathrm{pH} 7.8$ control or $\mathrm{pH} 7.8+\mathrm{Fe}$. The suspension of ferrihydrite was added according to the treatment design and mixed well with soils. The soil mixtures were then slightly air-dried to reach a gravimentric moisture content of about $15 \%$, passed through a sieve of $2 \mathrm{~mm}$ and stored at $4{ }^{\circ} \mathrm{C}$ before use (within 7 days).

\subsection{Soil incubation with ${ }^{15} \mathrm{~N}$ substrates}

In this study, a set of ${ }^{15} \mathrm{~N}$ tracing experiments were conducted to quantify process-specific and pool-specific $\mathrm{N}$ transformation rates. For each soil, Fe-treated or non-Fe-treated soils were weighed ( $20 \mathrm{~g}$ dry mass) into $150 \mathrm{~mL}$ conical flasks. Two $\mathrm{N}$ treatments were applied: ${ }^{15} \mathrm{~N}$-enriched $\left(\mathrm{NH}_{4}\right)_{2} \mathrm{SO}_{4}$ (10 atom\% excess) or ${ }^{15} \mathrm{~N}$-enriched $\mathrm{KNO}_{3}$ (10 atom\% excess). Each $\mathrm{N}$ treatment received $50 \mathrm{mg} \mathrm{N} \mathrm{kg}^{-1}$ soil at the beginning of incubation. All treatments were incubated at $100 \%$ water-holding capacity (WHC) at $28^{\circ} \mathrm{C}$ for 6 days in dark after $\mathrm{N}$ application. The experimental design and treatment application was set as a completely randomized block design, with three replicates per treatment (120 total experimental units comprising five soil sampling times). A total of $100 \%$ WHC was chosen to create an oxic-anoxic interface, in which the redox cycle of Fe oxide commonly exists. All the flasks were covered with polyethylene film punctured with needle holes to maintain oxic conditions in the headspace.

\subsection{Soil extraction and soil $\mathrm{N}$ analysis}

For soil mineral $\mathrm{N}$ analysis, three replicates for each treatment were extracted with $2 \mathrm{~mol} \mathrm{~L}^{-1} \mathrm{KCl}$ (5 to 1 extractant volume to soil mass ratio) at hours 0 and 0.5 and days 1 , 3 , and 6 after $\mathrm{N}$ application. The extracted soils were centrifuged at $1200 \mathrm{rpm}$ and the supernatants were frozen at $-20{ }^{\circ} \mathrm{C}$ until analysis. The contents of $\mathrm{NH}_{4}^{+}$and $\mathrm{NO}_{3}^{-}$were quantified colorimetrically on a GENESYS $10 \mathrm{UV}$ spectrophotometer (ThermoScientific, Madison, WI, USA) using the salicylate method and the single reagent method, respectively (Verdouw et al., 1978; Doane and Horwath, 2003). Isotope analysis of $\mathrm{NH}_{4}^{+}$and $\mathrm{NO}_{3}^{-}$was performed on aliquots of the extracts using a diffusion technique, by which $\mathrm{NH}_{4}^{+}$was distilled with $\mathrm{Mg}$ oxide and $\mathrm{NO}_{3}^{-}$was converted to $\mathrm{NH}_{4}^{+}$by 
Devarda's alloy and then distilled with $\mathrm{Mg}$ oxide. $\mathrm{The}^{\mathrm{NH}_{3}}$ volatilizes were trapped using a boric acid solution (Feast and Dennis, 1996; Zhang et al., 2011, 2013a). The ${ }^{15} \mathrm{~N}$ isotopic composition in the trapped $\mathrm{NH}_{3}$ volatilizes were then analyzed using an automated $\mathrm{C} / \mathrm{N}$ analyzer coupled to an isotope ratio mass spectrometer (Europa Scientific Integra, UK).

Fumigated or unfumigated soil was then extracted with $0.5 \mathrm{~mol} \mathrm{~L}^{-1} \mathrm{~K}_{2} \mathrm{SO}_{4}$ (5 to 1 extractant volume to soil mass ratio) at time 0 and 6 days after $\mathrm{N}$ application for soil microbial biomass N (MBN) determination (Brookes et al., 1985; Breland and Hansen, 1996; Dempster et al., 2012). The extracts were filtered and the supernatant stored at $-20^{\circ} \mathrm{C}$ until analysis. The total dissolved N (TDN) in the extracts was separated by distillation with $25 \mathrm{~mol} \mathrm{~L}^{-1} \mathrm{NaOH}$ solution (Brooks et al., 1989). The ${ }^{15} \mathrm{~N}$ isotopic composition in TDN was analyzed using an automated $\mathrm{C} / \mathrm{N}$ analyzer coupled to an isotope ratio mass spectrometer (Europa Scientific Integra, UK). MBN (calculated from 1 day $\mathrm{CHCl}_{3}-\mathrm{N}$ ) was calculated as the difference of TDN between fumigated and unfumigated soils (Brookes et al., 1985; Dempster et al., 2012).

\subsection{Analysis of Fe(II) production}

Reduced iron, $\mathrm{Fe}(\mathrm{II})$, was quantified using the ferrozine assay method (Stookey, 1970). Briefly, $0.1 \mathrm{~g}$ soil was extracted with $0.5 \mathrm{~mol} \mathrm{~L}^{-1} \mathrm{HCl}$ (Lovley and Phillips, 1987), and $100 \mu \mathrm{L}$ of extracts was added to $4 \mathrm{~mL}$ of color reagent $\left(1 \mathrm{~g} \mathrm{~L}^{-1}\right.$ Ferrozine in $50 \mathrm{mmol} \mathrm{L}^{-1}$ HEPES buffer $\mathrm{pH} 8$ ). After the color developed (approximately in $15 \mathrm{~s}$ ), the ferrous concentration was spectrophotometrically determined immediately by measuring the absorbance of the ferrozine-Fe(II) complex at $562 \mathrm{~nm}$. Standards of ferrous iron for the ferrozine assay were prepared with ferrous ethylene diammonium sulfate dissolved in $0.5 \mathrm{~mol} \mathrm{~L}^{-1} \mathrm{HCl}$ (Lovley and Phillips, 1986).

\subsection{Data calculation}

The gross $\mathrm{N}$ mineralization rate was calculated according to Kirkham and Bartholomew (1954) and Davidson et al. (1991). The net nitrification rate was calculated from the net increase in $\mathrm{NO}_{3}^{-}$concentration in the $\left(\mathrm{NH}_{4}\right)_{2} \mathrm{SO}_{4}$ treatment during the incubation period (Davidson et al., 1992). Microbial biomass ${ }^{15} \mathrm{~N}\left(\mathrm{MB}^{15} \mathrm{~N}\right)$ was calculated as $\mathrm{MB}^{15} \mathrm{~N}=\mathrm{F}^{15} \mathrm{~N} / 0.54$ (Brookes et al., 1985), where $\mathrm{F}^{15} \mathrm{~N}=\left(\mathrm{TD}^{15} \mathrm{~N}\right.$ in the digested fumigated sample $)-\left(\mathrm{TD}^{15} \mathrm{~N}\right.$ in the digested non-fumigated sample). Total dissolved ${ }^{15} \mathrm{~N}$ $\left(\mathrm{TD}^{15} \mathrm{~N}\right)$ of fumigated and unfumigated soils were calculated by multiplying the atom\% excess $\mathrm{TD}^{15} \mathrm{~N}$ and the amount of $\mathrm{N}$ in the form of TDN (Shen et al., 1984; Brookes et al., 1985).

\subsection{Statistical analyses}

Differences in soil $\mathrm{NH}_{4}^{+}$and $\mathrm{NO}_{3}^{-}$content, net nitrification rate, gross mineralization rate, and MBN content among different treatments were assessed by analysis of variance (ANOVA). Prior to any statistical analysis, the normality of the data was evaluated with a Shapiro-Wilk test, and appropriate transformation (e.g. natural-log transformation) of the data was carried out if the transformation improved the normality. Post hoc Tukey's honestly significant difference multiple comparisons of means or paired $t$ tests were used when appropriate to verify significant differences $(P<0.05)$ between treatments. All statistical analyses were performed with the SPSS statistical package (Huang, 2016).

\section{Results}

\subsection{Soil inorganic $\mathbf{N}$ concentrations during the incubation}

The dynamics of soil inorganic $\mathrm{N}$ concentrations during the 6-day incubation are shown in Fig. 2. In both low- and high$\mathrm{pH}$ soils with $\left(\mathrm{NH}_{4}\right)_{2} \mathrm{SO}_{4}$ application, the $\mathrm{NH}_{4}^{+}-\mathrm{N}$ concentrations significantly decreased over the course of incubation. For example, in the high-pH soil Fe oxide and $\left(\mathrm{NH}_{4}\right)_{2} \mathrm{SO}_{4}$ were applied; the $\mathrm{NH}_{4}^{+}-\mathrm{N}$ concentrations were 30.9 and $15.6 \mathrm{mg} \mathrm{N} \mathrm{kg}^{-1}$ soil at days 1 and 6 , respectively $(F=39.1$, $P=0.003)$. The $\mathrm{NO}_{3}^{-}-\mathrm{N}$ concentrations increased significantly in all the $\left(\mathrm{NH}_{4}\right)_{2} \mathrm{SO}_{4}$ treatments during the incubation. However, the $\mathrm{NO}_{3}^{-}-\mathrm{N}$ concentrations in all the $\mathrm{KNO}_{3}$ treatments did not fluctuate significantly during the course of incubation $(P>0.05)$ (Fig. 2c and d).

\subsection{Gross N mineralization and net nitrification rates}

The gross $\mathrm{N}$ mineralization rate in the high-pH soil was significant higher in the control than in the Fe-treated soil, whereas the opposite occurred in the low-pH soil (Fig. 3a) $(P<0.05)$. During the entire incubation, 22.4 and $7.80 \mathrm{mg} \mathrm{NH}_{4}^{+}-\mathrm{N} \mathrm{kg}^{-1}$ was mineralized in the high-pH soil without and with $\mathrm{Fe}$ oxide amendment, while 5.88 and $7.32 \mathrm{mg} \mathrm{NH}_{4}^{+}-\mathrm{N} \mathrm{kg}^{-1}$ was mineralized in the low-pH soil without and with Fe oxide amendment, respectively. No difference in gross $\mathrm{N}$ mineralization rate was found between the low- and high-pH soils with $\mathrm{Fe}$ oxide amendment, but the non-Fe-treated (control) high-pH soil had the highest gross $\mathrm{N}$ mineralization among all the treatments.

The net nitrification rate in the high-pH soil without Fe oxide amendment was $6.02 \mathrm{mg} \mathrm{N} \mathrm{kg}^{-1}$ soil day ${ }^{-1}$, the highest among all the treatments, while the smallest net nitrification rate was $2.41 \mathrm{mg} \mathrm{N} \mathrm{kg}^{-1}$ soil day ${ }^{-1}$ in the low-pH soil without $\mathrm{Fe}$ oxide amendment. Compared to the control, the addition of Fe oxide significantly decreased the net nitrification rate in the high-pH soil by $22.7 \%$, whereas $27.1 \%$ of net nitrification rate was increased by $\mathrm{Fe}$ oxide in the low-pH soil $(F=63.1 ; P=0.048)$ (Fig. 3b). 

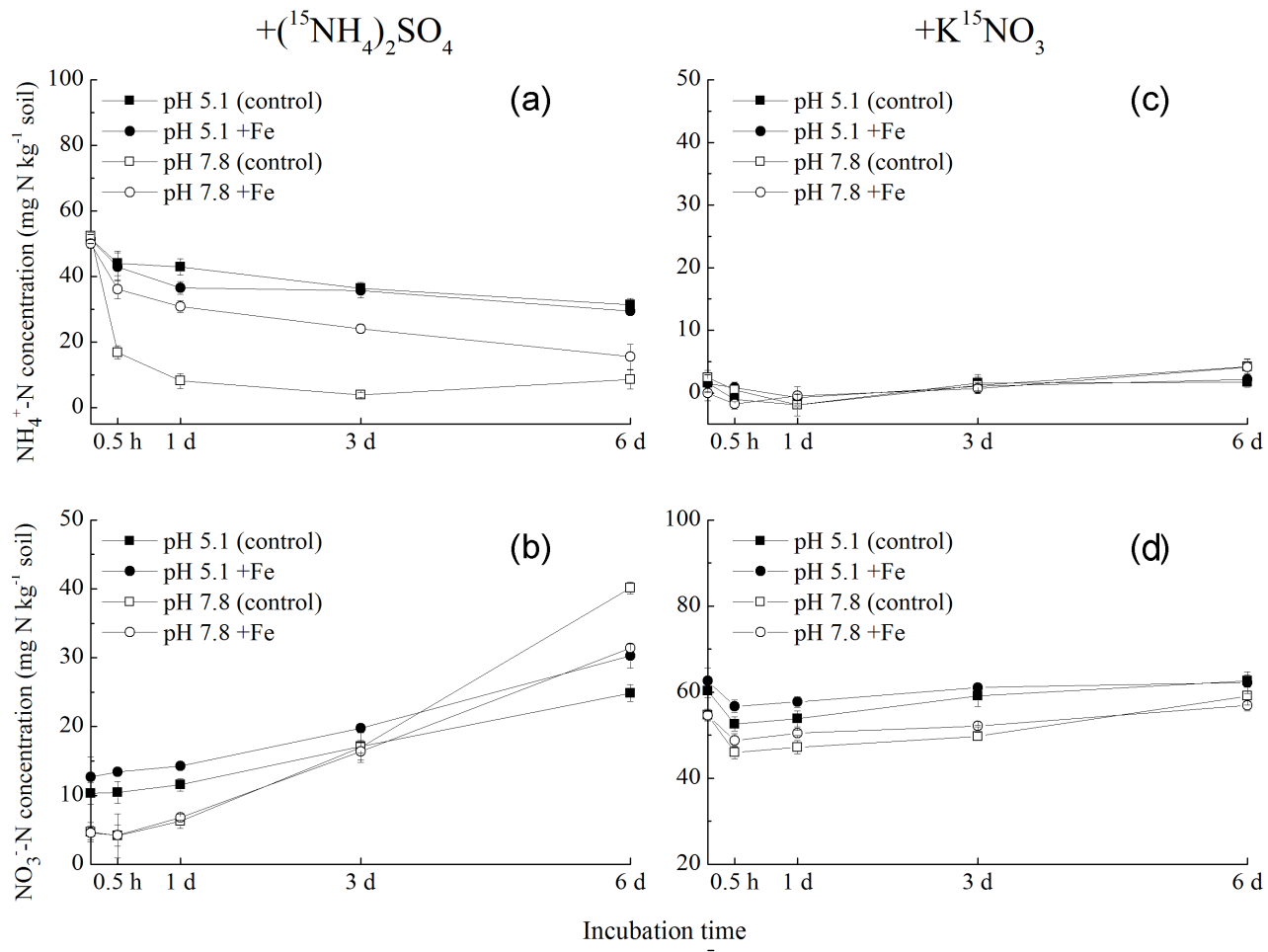

Figure 2. Effects of Fe oxide on $\mathrm{NH}_{4}^{+}-\mathrm{N}$ and $\mathrm{NO}_{3}^{-}-\mathrm{N}$ dynamics during 6 days by ${ }^{15} \mathrm{~N}$ tracing incubation at $28^{\circ} \mathrm{C}$ with soil moisture at $100 \%$ WHC. $\mathrm{NH}_{4}^{+}-\mathrm{N}$ and $\mathrm{NO}_{3}^{-}-\mathrm{N}$ concentrations were measured following the addition of $50 \mathrm{mg} \mathrm{N} \mathrm{kg}^{-1}\left({ }^{15} \mathrm{NH}_{4}\right)_{2} \mathrm{SO}_{4}(\mathbf{a}$ and $\mathbf{b})$ and $\mathrm{K}^{15} \mathrm{NO}_{3}(\mathbf{c}$ and d). Error bars represent standard deviation; $n=3$.
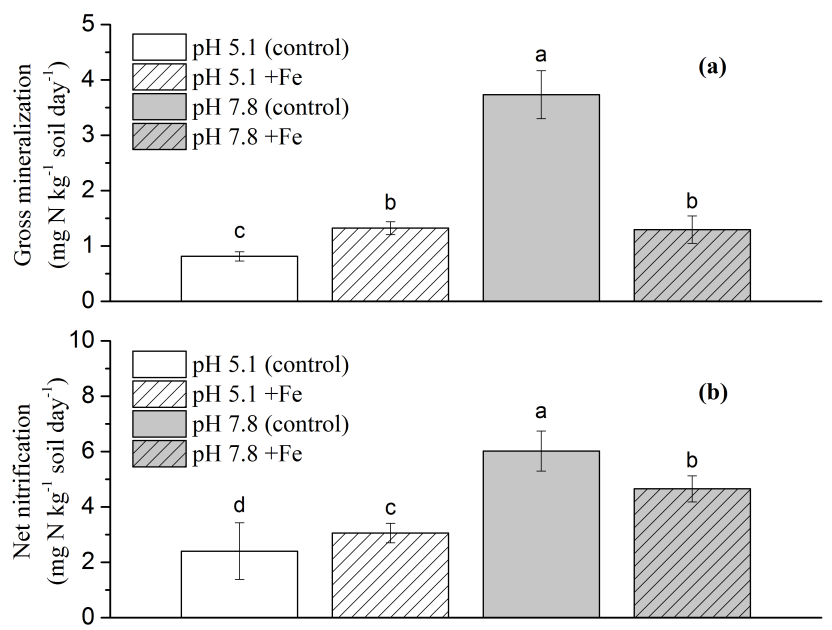

Figure 3. Effects of Fe oxide on gross mineralization rate (a) and net nitrification rate (b) during 6 days for soil samples incubated at $28{ }^{\circ} \mathrm{C}$ with soil moisture at $100 \%$ WHC. Error bars represent standard deviations; $n=3$. The different letters above the columns indicate a significant difference $(P<0.05)$.
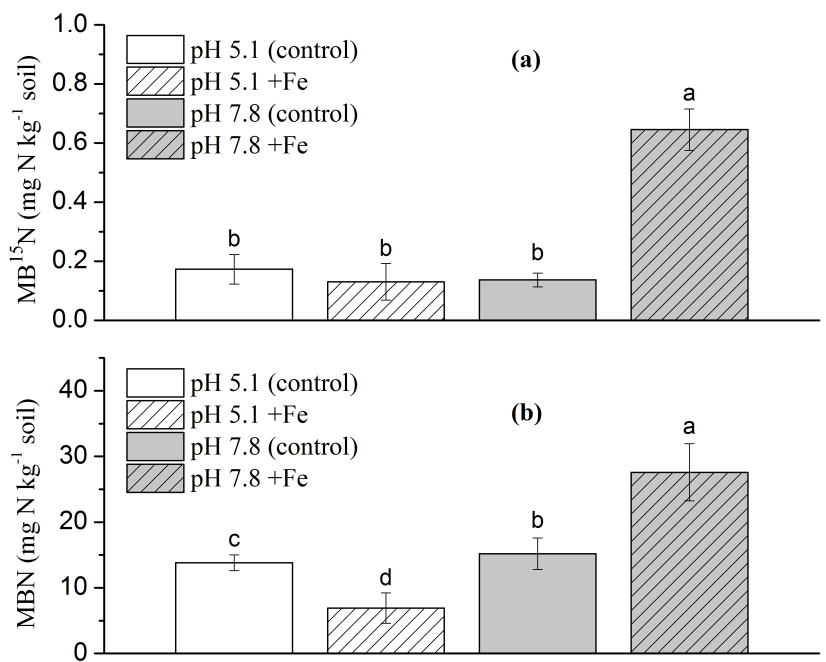

Figure 4. Effects of $\mathrm{Fe}$ oxide on $\mathrm{MB}^{15} \mathrm{~N}$ (a) and $\mathrm{MBN}$ (b) pools during 6 days with $\left({ }^{15} \mathrm{NH}_{4}\right)_{2} \mathrm{SO}_{4}$ treatment incubation at $28^{\circ} \mathrm{C}$ with soil moisture at $100 \%$ WHC. Error bars represent standard deviations; $n=3$. The different letters above the columns indicate a significant difference $(P<0.05)$. 


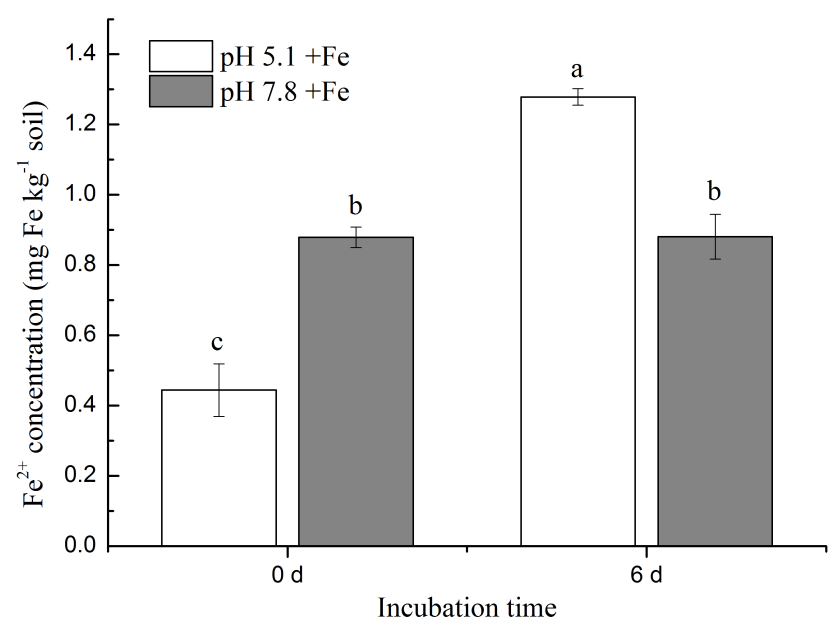

Figure 5. Effects of $\mathrm{Fe}$ oxide on concentration of $\mathrm{Fe}(\mathrm{II})$ $\left(0.5 \mathrm{~mol} \mathrm{~L}^{-1} \mathrm{HCl}\right.$ extractable) before and after 6 days with $\left({ }^{15} \mathrm{NH}_{4}\right)_{2} \mathrm{SO}_{4}$ treatment incubation at $28^{\circ} \mathrm{C}$ with soil moisture at $100 \%$ WHC. Error bars represent standard deviations; $n=3$. The different letters above the columns indicate a significant difference $(P<0.05)$.

\subsection{Microbial nitrogen immobilization}

The $\left({ }^{15} \mathrm{NH}_{4}\right)_{2} \mathrm{SO}_{4}$ amended soils were used to determine microbial $\mathrm{N}$ immobilization as affected by $\mathrm{Fe}$ oxide in the 6-day incubation (Fig. 4). The ${ }^{15} \mathrm{~N}$ content in $\mathrm{MB}^{15} \mathrm{~N}$ was $0.17 \mathrm{mg} \mathrm{N} \mathrm{kg}^{-1}$ soil in the low-pH soil with Fe oxide amendment, which was significantly lower than in the high-pH soil with $\mathrm{Fe}$ oxide amendment $\left(0.65 \mathrm{mg} \mathrm{N} \mathrm{kg}^{-1}\right.$ soil). The addition of Fe oxide had no significant influence on $\mathrm{MB}^{15} \mathrm{~N}$ in the low-pH soil, while $\mathrm{MB}^{15} \mathrm{~N}$ content in the high-pH soil was 3.7 times higher in the $\mathrm{Fe}$ oxide treatment than in the control (Fig. 4a). In the low-pH soil, the total N in MBN was $13.8 \mathrm{mg} \mathrm{N} \mathrm{kg}^{-1}$ soil in the control, which was significantly lower than it in the high-pH soil without Fe oxide amendment (15.2 $\mathrm{mg} \mathrm{N} \mathrm{kg}^{-1}$ soil). The addition of Fe oxide caused a significant decrease in $\mathrm{MBN}$ in the low-pH soil, while the opposite occurred in the high-pH soil $(P<0.05)$ (Fig. 4b). Compared to control, Fe oxide addition decreased MBN by $50 \%$ in the low-pH soil but increased it by $45 \%$ in the high$\mathrm{pH}$ soil.

\section{$3.4 \mathrm{Fe}(\mathrm{II})$ production}

The concentration of $\mathrm{Fe}(\mathrm{II})\left(0.5 \mathrm{~mol} \mathrm{~L}^{-1} \mathrm{HCl}\right.$ extractable $)$ in the soils with $\mathrm{Fe}$ oxide amendment before and after 6 days' incubation are shown in Fig. 5. In the low-pH soil amended with Fe oxide, the concentration of $\mathrm{Fe}$ (II) was increased from 0.44 to $1.28 \mathrm{mg} \mathrm{Fe} \mathrm{kg}^{-1}$ soil after the 6 days incubation. In the high-pH soil amended with Fe oxide, the concentration of $\mathrm{Fe}(\mathrm{II})$ did not change between day 0 and day 6 .

\section{Discussion}

In the present study, the addition of $\mathrm{Fe}$ oxide increased the net nitrification rate by $20.8 \%$ in the low-pH soil. The effect of $\mathrm{Fe}$ oxide on the nitrification rate varied with soil $\mathrm{pH}$, supporting our hypothesis. Nitrification is primarily dependent on $\mathrm{NH}_{3}$ availability and the activity of nitrifying microorganisms. A regression analysis assessing relationships among the rates of $\mathrm{N}$ transformation processes from 100 published studies with nearly 300 different organic and mineral soil materials concluded that the nitrification rate is controlled by the rate of ammonia released from soil organic-matter mineralization (Booth et al., 2005). The addition of Fe oxide had opposite effects on nitrification, stimulating it in low-pH soil $(\mathrm{pH}$ 5.1) $(F=63.13 ; P=0.048)$ and lowering it in high-pH soil ( $\mathrm{pH} 7.8)$.

The amount of substrate ammonia available for nitrification is dependent on the gross N mineralization rate. Gross N mineralization increased significantly in the low-pH soil with Fe oxide. An increase in $\mathrm{N}$ mineralization $\left(\mathrm{R}-\mathrm{NH}_{2} \rightarrow \mathrm{NH}_{3}\right)$ likely increased the availability of $\mathrm{NH}_{3}$, leading to an increase in nitrification. Generally, both AOA and AOB play roles in nitrification, but it is difficult for AOB to sustain ammonia oxidation in soil with low $\mathrm{pH}$ due to the high $\mathrm{pKa}$ of ammonia $\left(\mathrm{NH}_{3}+\mathrm{H}^{+} \rightarrow \mathrm{NH}_{4}^{+}\right.$; $\left.\mathrm{pKa}=9.25\right)$ (Kuroiwa et al., 2011). Since AOA have a much higher affinity for $\mathrm{NH}_{3}$ than AOB (Martens-Habbena et al., 2009), they generally dominates nitrification activity in acidic soils (Stopnišek et al., 2010; Gubry-Rangin et al., 2011; Isobe et al., 2012; Prosser and Nicol, 2012; Jiang et al., 2015b).

The high solubility of $\mathrm{Fe}(\mathrm{III})$ at low $\mathrm{pH}$ could also promote scavenging of hydroxylamine $\left(\mathrm{NH}_{2} \mathrm{OH}\right)$, an intermediate in nitrification (Vajrala et al., 2013), by the chemical reaction $2 \mathrm{Fe}^{3+}+2 \mathrm{NH}_{2} \mathrm{OH} \rightarrow 2 \mathrm{Fe}^{2+}+\mathrm{N}_{2}+2 \mathrm{H}_{2} \mathrm{O}+4 \mathrm{H}^{+}$(ZhuBarker et al., 2015). This assumption was supported by the significant increase in $\mathrm{Fe}(\mathrm{II})$ concentration at the end of the incubation in the low-pH soil with $\mathrm{Fe}$ oxide amendment (Fig. 5). Under low $\mathrm{pH}, \mathrm{Fe}(\mathrm{III})$ solubility is generally high (Weber et al., 2006). It was not absolutely certain that the $100 \%$ WHC soil moisture in our incubation provided a complete anoxic environment for the occurrence of anaerobic $\mathrm{NH}_{4}^{+}$oxidation into $\mathrm{NO}_{3}^{-}$or $\mathrm{NO}_{2}^{-}$by coupled $\mathrm{Fe}(\mathrm{III})$ reduction (Feammox). Thus, the process of Feammox cannot be used to explain exclusively the increase in the net nitrification rate in low-pH soil. Further studies are needed to fully understand the process of Feammox in the low-pH soil.

In the high-pH soil, iron oxide significantly decreased the net nitrification rate, likely due to increased inorganic $\mathrm{N}$ immobilization (Fig. 4b). Furthermore, the toxicity of $\mathrm{Fe}$ oxide on nitrifying microorganisms can be another important reason for Fe oxide decreasing nitrification at high $\mathrm{pH}$. For example, Meiklejohn (1953) demonstrated that high Fe $\left(>112 \mathrm{mg} \mathrm{L}^{-1}\right.$ ) was toxic to nitrifying bacteria.

Previous research showed that soil microbial communities prefer $\mathrm{NH}_{4}^{+}$to $\mathrm{NO}_{3}^{-}$as a source of $\mathrm{N}$ (Jansson et al., 1955; 
Recous et al., 1990; Zhang et al., 2013b). However, $\mathrm{NO}_{3}^{-}$immobilization was found to be high in undisturbed forest soils (Stark and Hart, 1997), suggesting that microbial biomass maybe flexible in utilizing different $\mathrm{N}$ sources. Besides the factors of inorganic $\mathrm{N}\left(\mathrm{NH}_{4}^{+}\right.$or $\left.\mathrm{NO}_{3}^{-}\right)$availability and microbial activity (Stark and Hart, 1997), Fe oxide is another factor affecting microbial $\mathrm{N}$ immobilization. In the low-pH soil, the addition of Fe oxide caused a significant decrease in MBN, while the opposite was found in the high-pH soil (Fig. 4b). This indicates that high solubility of $\mathrm{Fe}$ oxide in low-pH environment can impair the assimilation of $\mathrm{N}$ and reduce the size of the microbial biomass.

While Fe oxide in the low-pH soil decreased microbial $\mathrm{N}$ assimilation, the $\mathrm{Fe}(\mathrm{III})$ reduction process can release $\mathrm{Fe}$ bound $\mathrm{N}$ and lead to an increase in $\mathrm{N}$ mineralization and ammonification, thus increasing nitrification potential. The addition of $\mathrm{Fe}$ oxide had no influence on $\mathrm{MB}^{15} \mathrm{~N}$ in the low-pH soil, whereas in the high-pH soil, 3.7 times higher $\mathrm{MB}^{15} \mathrm{~N}$ was found in the $\mathrm{Fe}$ oxide treatment than in the control (Fig. 4a). The high $\mathrm{MB}^{15} \mathrm{~N}$ content in the high-pH soil with $\mathrm{Fe}$ oxide addition was probably related to the low activity of Fe oxide in the high-pH soil due to the low solubility of $\mathrm{Fe}$ (III) oxide (Weber et al., 2006). Further research is needed to explore the mechanism of how the addition of Fe oxide increases microbial $\mathrm{N}$ assimilation in the high-pH environment.

\section{Conclusions}

The addition of Fe-oxide-stimulated net nitrification and gross $\mathrm{N}$ mineralization rates but reduced microbial $\mathrm{N}$ immobilization in low-pH soil. The opposite was observed in high-pH soil. These findings indicated that Fe oxide has an important role in soil $\mathrm{N}$ transformations. The effect of $\mathrm{Fe}$ oxide on $\mathrm{N}$ transformations varies with $\mathrm{pH}$. Further studies should focus on $\mathrm{Fe}$ redox in different $\mathrm{pH}$ soils to develop the mechanistic understanding of how Fe oxide changes $\mathrm{N}$ mineralization and nitrification through abiotic and biotic-related processes to influence the production of $\mathrm{N}_{2}, \mathrm{~N}_{2} \mathrm{O}$, and $\mathrm{NO}_{2}^{-}$.

\section{Data availability}

Research data may be made available upon request at doi:10.6084/m9.figshare.3978216.

Author contributions. Xueru Huang and Xianjun Jiang designed the experiments, and Xueru Huang carried them out. Xueru Huang prepared the paper with contributions from coauthors. Xia ZhuBarker revised and edited the manuscript. Xianjun Jiang, Xia ZhuBarker, William R. Horwath, and Sarwee J. Faeflen helped with writing and English language checking.
Acknowledgements. This work was supported by the National Natural Science Foundation of China (41271267).

Edited by: S. Fontaine

Reviewed by: two anonymous referees

\section{References}

Bauer, I. and Kappler, A.: Rates and extent of reduction of Fe (III) compounds and $\mathrm{O}_{2}$ by humic substances, Environ. Sci. Technol., 43, 4902-4908, 2009.

Booth, M. S., Stark, J. M., and Rastetter, E.: Controls on nitrogen cycling in terrestrial ecosystems: a synthetic analysis of literature data, Ecol. Monogr., 75, 139-157, 2005.

Breland, T. A. and Hansen, S.: Nitrogen mineralization and microbial biomass as affected by soil compaction, Soil Biol. Biochem., 28, 655-663, 1996.

Brookes, P. C., Landman, A., Pruden, G., and Jenkinson, D.: Chloroform fumigation and the release of soil nitrogen: A rapid direct extraction method to measure microbial biomass nitrogen in soil, Soil Biol. Biochem., 17, 837-842, 1985.

Brooks, P. D., Stark, J. M., Mcinteer, B. B., and Preston, T.: Diffusion method to prepare soil extracts for automated ${ }^{15} \mathrm{~N}$ analysis, Soil Sci. Soc. Am. J., 53, 1707-1711, 1989.

Clément, J. C., Shrestha, J., Ehrenfeld, J. G., and Jaffé, P. R.: Ammonium oxidation coupled to dissimilatory reduction of iron under anaerobic conditions in wetland soils, Soil Biol. Biochem., 37, 2323-2328, 2005.

Davidson, E. A., Hart, S. C., Shanks, C. A., and Firestone, M. K.: Measuring gross nitrogen mineralization, and nitrification by ${ }^{15} \mathrm{~N}$ isotopic pool dilution in intact soil cores, J. Soil Sci., 42, 335-349, 1991.

Davidson, E. A., Hart, S. C., and Firestone, M. K.: Internal cycling of nitrate in soils of a mature coniferous forest, Ecology, 73, 1148-1156, 1992.

Davidson, E. A., Chorover, J., and Dail, D. B.: A mechanism of abiotic immobilization of nitrate in forest ecosystems: The ferrous wheel hypothesis, Global Change Biol., 9, 228-236, 2003.

Dempster, D., Gleeson, D., Solaiman, Z., Jones, D., and Murphy, D.: Decreased soil microbial biomass and nitrogen mineralisation with Eucalyptus biochar addition to a coarse textured soil, Plant Soil, 354, 311-324, 2012.

Ding, L. J., An, X. L., Li, S., Zhang, G. L., and Zhu, Y. G.: Nitrogen loss through anaerobic ammonium oxidation coupled to iron reduction from paddy soils in a chronosequence, Environ. Sci. Technol., 48, 10641-10647, 2014.

Doane, T. A. and Horwath, W. R.: Spectrophotometric determination of nitrate with a single reagent, Anal. Lett., 36, 2713-2722, 2003.

Feast, N. A. and Dennis, P. F.: A comparison of methods for nitrogen isotope analysis of groundwater, Chem. Geol., 129, 167-171, 1996.

Gubry-Rangin, C., Hai, B., Quince, C., Engel, M., Thomson, B. C., James, P., Schloter, M., Griffiths, R. I., Prosser, J. I., and Nicol, G. W.: Niche specialization of terrestrial archaeal ammonia oxidizers, P. Natl. Acad. Sci. USA, 108, 21206-21211, 2011. 
Hall, S. J. and Silver, W. L.: Iron oxidation stimulates organic matter decomposition in humid tropical forest soils, Global Change Biol., 19, 2804-2813, 2013.

Huang, X.: Effect of iron oxide on nitrification in two agricultural soils with different $\mathrm{pH}$, figshare, doi:10.6084/m9.figshare.3978216.v1, 2016.

Isobe, K., Koba, K., Suwa, Y., Ikutani, J., Kuroiwa, M., Fang, Y., Yoh, M., Mo, J., Otsuka, S., and Senoo, K.: Nitrite transformations in an N-saturated forest soil, Soil Biol. Biochem., 52, 6163, 2012.

Jansson, S. L., Hallam, M. J., and Bartholomew, W. V.: Preferential utilization of ammonium over nitrate by micro-organisms in the decomposition of oat straw, Plant Soil, 6, 382-390, 1955.

Jiang, X. J., Xin, X. P., Li, S. W., Zhou, J. C., Zhu, T. B., Müller, C., Cai, Z. C., and Wright, A. L.: Effects of Fe oxide on $\mathrm{N}$ transformations in subtropical acid soils, Sci. Rep-UK, 5, 8615, $2015 \mathrm{a}$.

Jiang, X. J., Hou, X. Y., Zhou, X., Xin, X. P., Wright, A. L., and Jia, Z. J.: $\mathrm{pH}$ regulates key players of nitrification in paddy soils, Soil Biol. Biochem., 81, 9-16, 2015 b.

Kirkham, D. and Bartholomew, W.: Equations for following nutrient transformations in soil, utilizing tracer data, Soil Sci. Soc. Am. J., 18, 33-34, 1954.

Kuroiwa, M., Koba, K., Isobe, K., Tateno, R., Nakanishi, A., Inagaki, Y., Toda, H., Otsuka, S., Senoo, K., Suwa, Y., Yoh, M., Urakawa, R., and Shibata, H.: Gross nitrification rates in four Japanese forest soils: heterotrophic versus autotrophic and the regulation factors for the nitrification, J. Forest Res., 16, 363373, 2011

Li, L., Pan, Y., Wu, Q., Zhou, X., and Li, Z.: Investigation on Amorphous ferric oxide acting as an electron acceptor in the oxidation of $\mathrm{NH}_{4}^{+}$under anaerobic condition, Acta Pedologica Sinica, 25, 184-190, 1988.

Li, Y., Yu, S., Strong, J., and Wang, H.: Are the biogeochemical cycles of carbon, nitrogen, sulfur, and phosphorus driven by the "FeIII-FeII redox wheel" in dynamic redox environments?, J. Soil Sediment, 12, 683-693, 2012.

Liptzin, D. and Silver, W. L.: Effects of carbon additions on iron reduction and phosphorus availability in a humid tropical forest soil, Soil Biol. Biochem., 41, 1696-1702, 2009.

Lovley, D. R. and Phillips, E. J. P.: Organic matter mineralization with reduction of ferric iron in anaerobic sediments, Appl. Environ. Microb., 51, 683-689, 1986.

Lovley, D. R. and Phillips, E. J. P.: Competitive mechanisms for inhibition of sulfate reduction and methane production in the zone of ferric iron reduction in sediments, Appl. Environ. Microb., 53, 2636-2641, 1987.

Luther, G. W., Sundby, B., Lewis, B. L., Brendel, P. J., and Silverberg, N.: Interactions of manganese with the nitrogen cycle: alternative pathways to dinitrogen, Geochim. Cosmochim. Ac., 61, 4043-4052, 1997.

Martens-Habbena, W., Berube, P. M., Urakawa, H., José, R., and Stahl, D. A.: Ammonia oxidation kinetics determine niche separation of nitrifying Archaea and Bacteria, Nature, 461, 976-979, 2009.

Meiklejohn, J.: Iron and the nitrifying bacteria, J. Gen. Microbiol., $8,58-65,1953$

Park, W., Nam, Y. K., Lee, M. J., and Kim, T. H.: Anaerobic ammonia-oxidation coupled with $\mathrm{Fe}^{3+}$ reduction by an anaero- bic culture from a piggery wastewater acclimated to $\mathrm{NH}_{4}^{+} / \mathrm{Fe}^{3+}$ medium, Biotechnol. Bioproc. E., 14, 680-685, 2009.

Prosser, J. I. and Nicol, G. W.: Archaeal and bacterial ammoniaoxidisers in soil: The quest for niche specialisation and differentiation, Trends Microbiol., 20, 523-531, 2012.

Recous, S., Mary, B., and Faurie, G.: Microbial immobilization of ammonium and nitrate in cultivated soils, Soil Biol. Biochem. 22, 913-922, 1990.

Roden, E. E., Sobolev, D., Glazer, B., and Luther, G. W.: Potential for microscale bacterial Fe redox cycling at the aerobicanaerobic interface, Geomicrobiol. J., 21, 379-391, 2004.

Sahrawat, K.: Ammonium production in submerged soils and sediments: The role of reducible iron, Commun. Soil Sci. Plan., 35, 399-411, 2004.

Sawayama, S.: Possibility of anoxic ferric ammonium oxidation, J. Biosci. Bioeng., 101, 70-72, 2006.

Schuur, E. A. and Matson, P. A.: Net primary productivity and nutrient cycling across a mesic to wet precipitation gradient in Hawaiian montane forest, Oecologia, 128, 431-442, 2001.

Senn, D. B. and Hemond, H. F.: Nitrate controls on iron and arsenic in an urban lake, Science, 296, 2373-2376, 2002.

Shen, S., Pruden, G., and Jenkinson, D.: Mineralization and immobilization of nitrogen in fumigated soil and the measurement of microbial biomass nitrogen, Soil Biol. Biochem., 16, 437-444, 1984.

Shrestha, J., Rich, J. J., Ehrenfeld, J. G., and Jaffe, P. R.: Oxidation of ammonium to nitrite under iron-reducing conditions in wetland soils: Laboratory, field demonstrations, and push-pull rate determination, Soil Sci., 174, 156-164, 2009.

Smolders, A. J., Lucassen, E. C., Bobbink, R., Roelofs, J. G., and Lamers, L. P.: How nitrate leaching from agricultural lands provokes phosphate eutrophication in groundwater fed wetlands: The sulphur bridge, Biogeochemistry, 98, 1-7, 2010.

Soil Survey Staff: Keys to Soil Taxonomy, United States Department of Agriculture, Washington, USA, 2014.

Stark, J. M. and Hart, S. C.: High rates of nitrification and nitrate turnover in undisturbed coniferous forests, Nature, 385, 61-64, 1997.

Stookey, L. L.: Ferrozine-a new spectrophotometric reagent for iron, Anal. Chem., 42, 779-781, 1970.

Stopnišek, N., Gubry-Rangin, C., Höfferle, Š., Nicol, G. W., Mandič-Mulec, I., and Prosser, J. I.: Thaumarchaeal ammonia oxidation in an acidic forest peat soil is not influenced by ammonium amendment, Appl. Environ. Microb., 76, 7626-7634, 2010.

Straub, K. L., Schönhuber, W. A., Buchholz-Cleven, B. E., and Schink, B.: Diversity of ferrous iron-oxidizing, nitrate-reducing bacteria and their involvement in oxygen-independent iron cycling, Geomicrobiol. J., 21, 371-378, 2004.

Vajrala, N., Martens-Habbena, W., Sayavedra-Soto, L. A., Schauer, A., Bottomley, P. J., Stahl, D. A., and Arp, D. J.: Hydroxylamine as an intermediate in ammonia oxidation by globally abundant marine archaea, P. Natl. Acad. Sci. USA, 110, 1006-1011, 2013.

Verdouw, H., Vanechteld, C. J. A., and Dekkers, E. M. J.: Ammonia determination based on indophenol formation with sodium salicylate, Water Res., 12, 399-402, 1978.

Wang, Y. and Newman, D. K.: Redox reactions of phenazine antibiotics with ferric (hydr) oxides and molecular oxygen, Environ. Sci. Technol., 42, 2380-2386, 2008. 
Wei, X., Vajrala, N., Hauser, L., Sayavedra-Soto, L. A., and Arp, D. J.: Iron nutrition and physiological responses to iron stress in Nitrosomonas europaea, Arch. Microbiol., 186, 107-118, 2006.

Weber, K. A., Achenbach, L. A., and Coates, J. D.: Microorganisms pumping iron: Anaerobic microbial iron oxidation and reduction, Nat. Rev. Microbiol., 4, 752-764, 2006.

Yang, W. H., Weber, K. A., and Silver, W. L.: Nitrogen loss from soil through anaerobic ammonium oxidation coupled to iron reduction, Nat. Geosci., 5, 538-541, 2012.

Zhang, J. B., Zhu, T. B., Cai, Z. C., and Müller, C.: Nitrogen cycling in forest soils across climate gradients in Eastern China, Plant Soil, 342, 419-432, 2011.

Zhang, J. B., Cai, Z. C., Zhu, T. B., Yang, W. Y., and Müller, C.: Mechanisms for the retention of inorganic $\mathrm{N}$ in acidic forest soils of southern China, Sci. Rep-UK., 3, 2342, doi:10.1038/srep02342, 2013a.
Zhang, J. B., Zhu, T. B., Meng, T. Z., Zhang, Y. C., Yang, J. J., Yang, W. Y., Müller, C., and Cai, Z. C.: Agricultural land use affects nitrate production and conservation in humid subtropical soils in China, Soil Biol. Biochem., 62, 107-114, 2013 b.

Zhu, X., Silva, L. C., Doane, T. A., and Horwath, W. R.: Iron: the forgotten driver of nitrous oxide production in agricultural soil, Plos One 8, e60146, 2013.

Zhu-Barker, X., Cavazos, A. R., Ostrom, N. E., Horwath, W. R., and Glass, J. B.: The importance of abiotic reactions for nitrous oxide production, Biogeochemistry, 126, 251-267, 2015. 